\title{
The Gentrification of Human Rights
}

Andrew Fagan

\begin{abstract}
This article addresses what is increasingly perceived as a crisis of human rights. While contemporary critiques of human rights address a diverse set of challenges and issues, this article focuses specifically on the "populist" demagogic challenge to human rights within those notionally liberal-democratic societies in which human rights have been typically considered most secure. While agreeing with those who have argued that human rights is in crisis, in part, because of its relationship with neoliberalism, this article goes beyond this argument and outlines a way of understanding that relationship through identifying what I term the "gentrification of human rights." This article outlines the concept of the gentrification of human rights, while also seeking to demonstrate how gentrification restricts the ability of human rights to engage robustly with rising deprivation, inequality, and marginalization within affluent, "liberal-democratic" societies. It also presents some of the key challenges that confront human rights.
\end{abstract}

"A very popular error: having the courage of one's convictions; rather it is a matter of having the courage for an attack on one's convictions."

Nietzsche (The Antichrist, 1895)

Andrew Fagan is an internationally-renowned human rights scholar. He is currently the codeputy director of the University of Essex's Human Rights Centre. Andrew's research focuses upon the relationship between human rights and identity politics and is developing a critical perspective upon the increasingly evident shortcomings of liberal democracy. 


\section{HUMAN RIGHTS IN CRISIS: NON-ACADEMIC CHALLENGES}

There is an ongoing trend within academic human rights circles that depicts the socalled, and much celebrated, "age of human rights" as giving way to a state of crisis. Other human rights academics dispute this depiction and remain optimistic about the capacity of human rights to realize its promise. Human rights optimists point to the existence of a robust and comprehensive body of international human rights law and also point to the apparent weaknesses and contradictions of the pessimists' arguments. ${ }^{1}$ If the fate of human rights was entirely dependent upon resolving academic debate and argument, those who support human rights would have little cause for concern. In the expectation that I am likely to receive a similar response to that meted out to the pessimists who come before me, I nevertheless contend that human rights is, indeed, in real trouble.

One of the most serious threats to human rights comes not from disillusioned, pessimistic scholars lamenting yet another failed "god," but rather from sections of the electorate within many societies in which, what I shall refer to as demagoguery, (rather than populism), is on the rise. ${ }^{2}$ While demagoguery does not speak for "the people" in their entirety (which political platform could ever really achieve that?), it undoubtedly constitutes a grave and serious threat to what has typically been referred to as a liberal-democratic order within a growing number of societies. Widely lauded as the dominant political idiom of our age, human rights has been a core component of this liberal order for several decades. ${ }^{3}$ It comes as little surprise, then, that a concerted challenge to that order should extend to include human rights. Indeed, "human rights" features frequently as a vaguely defined, or empty signifier in repeated demagogic assaults upon the liberal, rights-evoking order. Dependent as it is upon simplifying narratives, demagoguery has, in part, achieved its electoral and political successes as a consequence of its ability to characterize human rights as hostile to the concerns of the many "ordinary" citizens from whom demagogues seek to gain electorally significant support. For opponents and supporters alike, critical attitudes towards human rights have become emblematic of illiberalism. Through associating the defense of human rights with what is presented as the elitist, selfassured attitudes of a socially and politically unrepresentative constituency of people, demagoguery increases its appeal and accelerates the forces that seek to condemn the human rights community to the status of an electorally unpopular minority. ${ }^{4}$ Having persistently focused on the worst atrocities perpetrated beyond the frontiers of a purportedly liberaldemocratic "Western" order, the human rights community now finds itself targeted at home, where it has often paid little attention to the travails of fellow citizens. Demagoguery is real enough and there seems to be little prospect of its imminent demise. How should the human rights community respond to the challenges it presently faces? This is a profoundly important question. How the human rights community addresses and answers this question will, I strongly believe, largely determine the fate of human rights in the proceeding decades of the twenty-first century. If the human rights community fails to critically engage with the growing domestic challenges that it confronts, it is highly likely that it will experience the same fate as that which appears to await other constituents of what is cast as the liberal elite; an unedifying descent into a socially exclusive, politically unpopular credo for a diminishing number of supporters, with ever diminishing influence beyond their own social enclaves. 
How, then, is the human rights community likely to respond to these challenges? I suspect, and recent reports suggest, that the standard response may only serve to hasten its decline. The human rights community typically does not respond well to criticism and critique. ${ }^{5}$ Not being entirely for human rights is often construed as setting oneself against human rights. In respect to the current demagogic assaults upon human rights, this stance may seem reasonable. After all, how can an individual be expected to constructively respond to, or even develop a dialogue with, people who are so resolutely hostile? It is easier for people to resign themselves to irreconcilable differences. It is easier to denounce the views of many Trump or Brexit supporters as "deplorable," to coin Hillary Clinton's entirely counter-productive phrase during the 2016 US presidential campaign. ${ }^{6}$ The views and interests of many such groups are fundamentally illiberal and incompatible with respect for human rights. As such, many human rights supporters may consider themselves duty-bound to reject these views and, given an enduring belief in individuals' ultimate responsibility for their professed views and commitments, to extend that rejection to those who espouse them: deplorable views become deplorable people. ${ }^{7}$

However, an attack-based defense strategy is likely to be both a pragmatic mistake and constitute a failure to engage with deep shortcomings within the human rights community and the doctrine it espouses. In distinctly pragmatic terms, one might caution against an overly righteous dismissal of opponents' prejudices since, after all, these adversaries are fellow citizens and voters who are (increasingly it would appear) in a position to affect governments' support for human rights, both domestically and internationally. As Hillary Clinton discovered, some dismissive responses serve to lend weight to a demagogic depiction of liberals and human rights defenders as elitist and intolerant of those who do not espouse a similar faith in liberal values and norms. This depiction merely confirms the claims demagogues routinely make about liberals and human rights supporters being, at best, out of touch and aloof from more domestic, everyday concerns of many voters. Given the dependency of human rights upon governmental political support (however "symbolic" this support has typically been), a more pragmatic standpoint may merit some consideration. However, advocating pragmatism is not the objective of this article.

The more significant objective of this article is to engage with the consequences for human rights of simply and summarily dismissing on-going criticism. Most importantly, this article will address how the prevailing dismissal of criticism in this specific area of theory and practice will prevent the community from developing an urgently required understanding of its deeper inability to address effectively some of the weightiest challenges which confront societies at risk of demagogic authoritarianism. Developing this selfcritical understanding will require an acknowledgement of (and subsequent engagement with) deep internal shortcomings and limitations. The on-going crisis of human rights is not merely a consequence of demagogues stoking their supporters' prejudices and hostilities. The human rights community has also contributed to the very conditions, which now pose a threat to the community and its doctrine. Central to the self-undermining predicament of human rights is, I shall argue, its relationship with neoliberal capitalism and the particular way in which this relationship has deeply influenced significant, if not constitutive, elements of the human rights community. 


\section{HUMAN RIGHTS AND NEOLIBERAL CAPITALISM}

It is part of what I shall term the pernicious "genius" of capitalism that all of us who are exposed to its various manifestations unavoidably reproduce its commodifying and objectifying "logics" merely as a consequence of being and surviving, irrespective of whether we are passionate supporters or vociferous opponents of capitalism's global hegemony. ${ }^{8}$ Human rights is no exception. As a core component of a liberal-democratic political order, human rights has (in varying ways) necessarily forged a relationship with the economic philosophy, practices, and institutions that accompany, if not establish, a liberal rights-based order. The relationship between human rights and capitalism more generally is unquestionably highly complex and multifaceted. While there are undoubtedly many within the human rights community who are wary of endorsing a human rights-based accommodation with capitalism, there are a great many examples of such endorsement, from both sides of the relationship. For example, human rights has been endorsed by many global financial institutional bodies, such as the International Monetary Fund and the World Bank, both of which proudly proclaim the promotion of human rights as a central objective of their roles in regulating global trade and promoting economic growth. ${ }^{9}$ Similarly, many transnational corporations have endorsed a United Nations Global Compact, which provides a collection of Guiding Principles for how capitalist enterprises may be carried out in a human rights-compliant spirit and manner. ${ }^{10}$ Commercial enterprises that abide by these effectively unsupervised and legally unenforceable standards thereby receive a symbolic human rights-based stamp of approval. Those states within the UN human rights system that typically consider themselves to be most supportive of international human rights legal provisions and norms are also, of course, stalwart defenders of the market. It seems inconceivable for human rights to have achieved such a global presence and status had the international financial order and the more powerful constituents of that order found good cause and reason systematically to oppose human rights. In many significant respects, human rights has either always been amenable to the broad philosophy and practice of capitalism, or has adapted in order to ensure its own survival within such an order. Either way, there really is no doubt that an amenable relationship exists between the two, and many within the human rights community (and liberalism more broadly) have no objections to this state of affairs and positively approve of it.

"Capitalism" is a ludicrously reductivist and falsely simplifying label for the profoundly complex and evolving set of realities to which it is applied. However, a great deal of discussion and debate has raged over what is typically described as the neoliberal manifestation of capitalism, which has exerted profound influence over politics, law, and society in recent decades, particularly within those societies in which demagoguery is also in ascendency. Defenders of neoliberalism credit it with delivering an extensive range of benefits as a consequence of its uncompromising commitment to expanding economies and economic growth. Individuals, who have not consistently opposed other manifestations of capitalism, have condemned and criticized neoliberalism for the rapidly growing economic inequalities it appears to produce as a consequence of removing external regulatory procedures and mechanisms previously developed to constrain what were thought to be "excessive" inequalities. In many parts of the developed and developing world, neoliberalism is strongly associated with declining public expenditure, shrinking welfare, and waning 
social support. It is also, particularly in some of the world's most affluent societies, strongly associated with rapidly expanding levels of socio-economic inequality.

The modern human rights movement (conventionally dating back to the immediate post-World War II era) was not established under a neoliberal economic hegemony. Nor did the effectively universal support for some form of capitalism amongst the key constituents of the international financial, political, and legal orders exist, as is the case now. Some credit the establishment of social rights as human rights to this particular period, given the combined forces of the emerging European welfare statesystem within European liberal-democracies and the Soviet Union's opposition to capitalism and the market. ${ }^{11}$ However, social rights were never intended to pose a threat to those capitalist liberal democracies, which were prepared to support their inclusion within international human rights law. While this accommodation with capitalism seems unavoidable (if human rights were to secure such prominence within this order), it established a space in which this relationship would develop and complicate the practice of human rights. Specifically, it has more recently led to recognition of deep and wide-ranging affinities between human rights and neoliberalism.

It may be surprising to many human rights supporters of social rights, in particular, to learn of the relationship between neoliberalism and human rights. However, there is an established body of academic scholarship that has identified numerous close connections between more recent manifestations of human rights and the philosophy and practice of neoliberalism. For example, in his analysis of the connections between neoliberalism and human rights, David Harvey writes,

\footnotetext{
[T]he two movements are deeply implicated in each other. Undoubtedly, the neoliberal insistence upon the individual as the foundational element in politicaleconomic life opens the door to individual rights activism. But by focusing on those rights rather than on the creation or recreation of substantive and open democratic governance structures, the opposition cultivates methods that cannot escape the neoliberal frame. ${ }^{12}$
}

Along with several others who have analyzed the affinities and connections between human rights and neoliberalism, Harvey argues that the institutionalized praxis of human rights draws upon a similar stock of ideals and commitments as neoliberalism: naïve individualism, the de-politicization of structural, systemic drivers of injustice, and an undue reliance placed upon the rule of law as the bulwark against the abuse of power. ${ }^{13}$ More recently, the historian Samuel Moyn has provided a meticulous analysis of the overlapping institutional and conceptual connections between neoliberalism and human rights since the late 1970 s. ${ }^{14}$ For Moyn, the single greatest victim of this relationship has been an ever-declining support for the redistributive social democratic ideal of material equality, which he insists should be integral to the entire human rights project. ${ }^{15}$ The human rights community continues to include groups and individuals who seek to combat relative poverty and inequality, but Moyn insists they are a diminishing constituency with a declining presence and influence within the broader human rights movement and community. ${ }^{16}$

It is reasonable to conclude that this body of research has correctly identified what should be a profoundly disturbing relationship for many within the human rights community. The research also offers important insights into the long-standing 
debates within the human rights community over the status of social rights, which continue to rage even now. However, this body of research has not addressed a puzzling question, which the relationship between neoliberalism and human rights raises. Human rights has been described by some human rights theorists as a "fighting creed."17 Human rights is typically conceived as offering a morally authoritative vehicle for combating injustices, such as deprivation, inequality, and marginalization. Many human rights supporters often simply assume that any commitment to human rights entails a corresponding commitment to social justice. Human rights appeals to many people precisely because it has a perception of being untarnished by partial interests and power. Therefore, why do so many who, to varying extents and in a variety of ways, identify with the cause of justice (itself variously conceived) nevertheless support forms of human rights that are, at the very least, closely entwined with neoliberalism? Why is the human rights community not concertedly and unequivocally opposed to neoliberalism? Why is the community not more uncompromisingly oppositional to the prevailing status quo?

\section{THE GENTRIFICATION OF HUMAN RIGHTS ${ }^{18}$}

Opponents of neoliberalism have a tendency towards demonizing those individuals and constituencies most closely associated with it. This is understandable. The selfdeclared "masters of the universe" would have us all believe that they are the sole architects and exponents of a globalizing order, which financially rewards them so obscenely well. I shall refrain from demonization, however. The reality is that we all play our part in sustaining this order. What I refer to as the pernicious genius of neoliberalism reaches into the very forces that ostensibly oppose it. Neoliberalism assimilates elements of its potential opposition in the very form and substance that this ostensive opposition often assumes. The varying standpoints we adopt and the tools we deploy in our attempts to lead a good, equitable, humane life amidst profound inequalities and extensive social pathologies all too often either offer up no real opposition to the prevailing exploitative order or, unbeknownst to many, actually reinforce the deprivation, inequality, and marginalization it entails. Gentrification epitomizes this attempt to live wrong life rightly through its commodification of "good living." 19

Ruth Glass first coined the term "gentrification" and defined it as specifically denoting the residential redevelopment of previously working-class and industrialized urban neighborhoods. ${ }^{20}$ The phenomenon and thus the term which describes it is, however, so much more profound than the mere transformation of property ownership and use in areas such as the Bowery in New York, Docklands in London, the 10th Arrondissement in Paris, or Kreuzberg in Berlin. Far more significantly, gentrification is routinely depicted as a fundamentally progressive and transformative force, which exposes previously dark and dubious (if not downright dangerous) places to the light of liberal Modernity. As such, gentrification is defended not merely or exclusively as a housing market phenomenon, whose principal beneficiaries are developers, estate agents, property owners, mortgage providers, conveyancers, and chic retail outlets, but as part of a far more significant trend towards overcoming the past and refashioning the world for the better. Hence, the validity and need to engage with gentrification as a socially normative phenomenon has far wider implications for the societies in which it exists. 
Proponents typically defend gentrification, viewing it as being good, not just for those with the means and opportunity to inhabit the allegedly redeemed environments, but for everyone else as well. The inhabitants of many such neighborhoods used to live only amongst their "own kind" and all too often fell victim to the moribund, illiberal traditions and lifestyles of the urban deprived. Through this broad view, impoverishment obstructs the development of civic values and even of civil society itself. It produces and nourishes reactionary, sometimes brutalized, ways of being and believing. For those who defend it as a social and political good, gentrification offers the best (if not only) means of progressively transforming these neighborhoods. As well-educated, well-resourced, "responsible" (liberal) citizens take up their homes within these formerly dark places, they provide positive role models for the indigenous population to emulate. The neighborhoods become more liberal. Crime decreases and the streets are cleaner. As one academic supporter of gentrification declares, "gentrification rebalances a concentration of poverty by providing the tax base, rub-off work ethic, and political effectiveness of a middleclass and in the process improves the quality of life for all a community's residents. It is the rising tide that lifts all boats." 21

Another academic endorsement of gentrification provides a more detailed and substantive account of its purported benefits to both the newly arrived and the longstanding inhabitants of such neighborhoods. Thus, Peter Byrne contends that "gentrification is good on balance for the poor and ethnic minorities." 22 He goes on to claim that gentrification benefits low-income residents economically, by "expanding employment opportunities in providing locally the goods and services that more affluent new residents can afford." 23 Gentrification also heralds political benefits by creating "urban political fora in which affluent and poor citizens must deal with each other's priorities in a democratic process." 24 Finally, Byrne credits gentrification with producing distinct social benefits as "[n]ew more affluent residents will rub shoulders with poorer existing residents on the streets, in shops, and within local institutions, such as public schools." 25 The justifications for gentrification thereby burst the definitional boundaries of its narrow, original meaning. Gentrification is a means by which the moribund industrialized past can finally transcend, as well-resourced, liberally-motivated "progressives" strive to make the world a better place to live in. ${ }^{26}$ It is important to note, at this point, that the socially normative dimension of gentrification ties social and even moral development to a system of market-based commercial transactions, which only some (the gentrified) have the means to participate in. Others (the non-gentrified) are thought nevertheless derivatively to benefit from this process. One might go so far as to say that gentrification (in both the narrow and broad understandings, which I draw upon in this article) is thought to "trickle down" to these others, who will, in time, come to emulate the values, norms, and commitments of their wealthier, allegedly progressive, neighbors.

As I previously stated, gentrification must be understood in its broader, socially normative sense if we are to understand its appeal for many and its wider social and political significance. This broader conception of gentrification comprises a collection of dispositional values that have been associated with the emergence of a new social demographic referred to as the "radical new middle classes," which began to attract sustained academic attention from the 1970s onwards. ${ }^{27}$ The chronology is particularly pertinent, since it closely corresponds with the acceleration of gentrification (in the narrower sense), while also paralleling the period when human 
rights began to attract far greater attention and interest amongst particular social groups within what many now refer to as post-industrial societies. ${ }^{28}$ As I shall proceed to demonstrate, the radical new middle classes are a highly significant constituent of the human rights community within post-industrial societies and understanding the defining attributes of this constituency is essential to the account I shall present of that community's character and standing.

Growing out of the categorization of modern, complex societies as "post-industrial," the post-materialist thesis rests upon a number of claims, two of which are central. ${ }^{29}$ The first is that within affluent, post-industrial societies, the arduous struggle for basic survival has been achieved. The post-war economic boom and sustained growth have lifted everyone, even the poorest, out of abject poverty and lifethreatening deprivation. As one of the principal authors of post-materialism stated: "[i]n short, people are safe and they have enough to eat." 30 In addition, and particularly within those post-industrial societies with established public welfare systems, people have secure access to a range of core forms of protection and provision, such as rising levels of education (and educational attainment), legallysecured entitlements to health-care and social security, unemployment provision, and financial support in times of individual need, such as illness, accident, or disability. The second core claim is that the struggle against capitalism is over. ${ }^{31}$ Progressive political forces within post-industrialized societies no longer seek to oppose or even overcome this emerging new form of postindustrialized capitalism, but instead, pursue an increasingly eclectic set of political interests and objectives made possible by it, from environmentalism, the peace movement, and animal rights, to human rights. ${ }^{32}$ Politics is no longer constrained by binary class distinctions and their dependence upon crude instrumental rationality. ${ }^{33}$

The embodiment of this new set of dispositional values was evident in the rise of radical new middle classes and the so-called new social movements, which some formed, many participated in, and even more identified with. Feeling as though they had been liberated from the bonds of wealth-fixated interests and concerns, many amongst the new middle classes were able to focus on what they increasingly considered to be inherently moral or humanitarian causes, as opposed to more overtly partial, political interests. As an early observer wrote of members of the antinuclear arms movement, they "tend to be far less oriented to the achievement of economic or material rewards for their supporters. They are instead more typically concerned with issues of a moral or humanitarian nature." 34 The widespread desire to ennoble one's economic standing by creating or associating with morally or culturally distinguished symbols and causes has long been practiced amongst the "older" middle classes, or bourgeoisie, if you prefer a more overtly Marxist designation. ${ }^{35}$ The new middle classes transform this long-standing practice into a veritable raison d'etre, as a whole body of empirical research repeatedly highlights the importance of liberal, identity-constituting commitments and causes for many amongst the new middle classes. ${ }^{36}$

It is also debatable how many typically well-educated, materially secure individuals may be prepared to accept the continuing reference to being middle class, new, or otherwise. Since, in addition to the diminished interest in the politics of wealth and capital, many members of the new social movements are recognizable by their commitment to a largely liberal-individualist set of post-materialist values and a 
corresponding absence of any consciousness of themselves as belonging to a class: they are marked by their lack of any sustained consciousness of being a class in and of themselves. ${ }^{37}$ Indeed, subjective class-based interests have become increasingly obsolete. As Inglehart stressed, post-materialists are identifiable by their rejection of class-based politics and political parties. ${ }^{38}$ Many amongst the new middle classes favor political parties and causes considered liberal and progressive. ${ }^{39}$ Their very "radicalism" lies in their ability to perceive the need to both experiment with living and establish alternatives to the fast-expiring moribund appeal of traditional socialist or workers-based parties and movements. Alvin Gouldner expresses this clearly when he states that the new class "is a center of whatever human emancipation is possible in the foreseeable future." 40 Indeed, Gouldner speculated that the radical new middle classes represent "the best card that history has presently given us to play." 41

\section{HOW DOES THIS ALL CONNECT TO THE GENTRIFICATION OF HUMAN RIGHTS?}

There are many different strands and aspects to what I term the gentrification of human rights. Several are particularly important to my ensuing line of analysis and argument. Thus, the gentrification of human rights refers to the widespread displacement of what was an underdeveloped human rightsbased engagement with deprivation, inequality, and social marginalization within so-called post-industrialist societies. The gentrification of human rights generally and characteristically fails to concertedly identify and effectively engage with systemic and structurally based forms of injustice. A gentrified approach to human rights within such societies fails to identify and engage with fundamental forms of social and economic injustice precisely because it is itself a product of these systemic and structural forces: it is part of the very predicament it largely fails to discern. The liberal individualism that is central to the gentrification of human rights is infused with a set of presuppositions concerning the basis and causes of what is often construed as constituting success and failure within post-materialist societies. It is often simply assumed that many individuals thrive or languish largely as a consequence of their own dispositions, commitments, and lifestyle choices, rather than as a result of partially motivated structures, policies, and laws.

The gentrification of human rights is also characterized by a set of assumptions about the nature of the post-materialist societies which support it, and which coincide with a set of assumptions and presuppositions concerning the extent to which the relative inequalities found within such affluent, "liberal" societies may be legitimately considered as severe or serious enough to justify describing them as human rights violations. There have been repeated attempts by influential theorists and practitioners to defend the normative legitimacy of human rights by seeking to pare down their content and scope. ${ }^{42}$ Insisting that so-called "human rights inflationism" serves to undermine the impartiality and moral authority of the doctrine, human rights supporters have been repeatedly urged, by those wary of what they see as overlyambitious normative objectives, to focus on only the worst forms of "inhumanity," in which only life-threatening socio-economic harms may be included. ${ }^{43}$ Of course, not everyone has accepted such a counsel of restraint. However, the sentiment, which it draws upon and evokes, is a well-established component of many peoples' understanding of what human rights is, or should be. By connecting it to the specifically post-materialist component of the gentrification of human rights, we can 
see how it reinforces a view that relative inequalities and poverty are no longer morally compelling within societies where, to repeat the above quotation, "people are safe and they have enough to eat." 44

Moving on from this claim about the satisfaction of basic needs within postmaterialist societies, the gentrification of human rights also rests upon a set of presuppositions and assumptions about the extent to which affluent, liberal societies, while not perfect, nevertheless are at their core essentially just. Thus, human rights are characteristically associated with universal moral principles of justice, fairness, and basic equity. Societies, in which respect for human rights is considered an integral part of the legal order and the public and civic culture, may thereby be considered societies whose basic structures are sufficiently just and fair. A human rights-respecting society, it seems to follow, is not one in which the basic rules and procedures governing public authorities' regulation of individual enterprise (in the broad sense of that term) are fundamentally rigged or discriminatory towards any section of society. This is not to say that individual violations may sometimes occur, as they undeniably do: a defining component of most liberal political philosophies is the claim that no society or order can ever be perfectly just. However, exceptional injustices do occur and when they do, there exist distinctly legal remedies (if the society is sufficiently human rights-respecting), which will provide individual redress and compensation. There may be all sorts of things that many of us dislike about our human rights-respecting societies, but these supervene the fundamental assumption that the extent to which those societies are basically just is confirmed by the extent to which they, generally speaking, legally uphold and respect human rights commitments. ${ }^{45}$ To conclude that one's own society adequately respects human rights, where human rights are the dominant political idiom for what constitutes "justice" and "fairness," dispels any deeper anxieties about the possible need for fundamental, radical change. Violations which occur, are considered exceptional and not endemic or characteristic. ${ }^{46}$ The system is not rigged against those who fare badly within it. In keeping with the post-materialist values of the gentrified, and by dint of an evident circularity in reasoning, the existence of human rights provides basic reassurance that the "grand narrative" types of political conflict and struggle are over. We may thereby focus on the more personal, lifestyle-type concerns, which the human rights framework ensures that everyone can enjoy. In human rightsrespecting, liberal-democratic, and sufficiently affluent societies, human rights exist to the extent that (almost everyone) enjoys an opportunity of leading a minimally "good" life. Beyond this threshold, what individuals make of their lives is a matter of concern only to them as sufficiently free agents.

Finally, and following on the end of the grand narrative political struggle, a gentrified approach to human rights largely supports the post-materialist view that the struggle against capitalism is over. Those who dispute the alleged inevitability of capitalism are susceptible to being dismissed as unduly infected by partial (orthodox Marxist) ideology. "Genuine" progressives, in contrast, accept that the key challenge consists of determining the type of capitalism we would prefer our societies be characterized by. Thus, even some of those individuals who are anxious about the harmful effects of capitalism typically counsel the need to contain and ameliorate capitalism where these harms cross the human rights threshold. ${ }^{47}$ 
It would be churlish to deny that the period of neoliberalism within affluent liberaldemocratic societies has not witnessed significant social, legal, and material developments. Most significantly for many human rights supporters, has been the extension of what Kathryn Sikkink refers to as "recognition rights" to a diverse rainbow alliance of various groups who lacked any effective form of legal protections against the systematic discrimination and persecutions they previously suffered. ${ }^{48} \mathrm{In}$ addition to specific rights successes, there is also no denying that the human rights movement rose to global prominence during a period coinciding with neoliberalism. As a result, more people became aware that they were, in some sense, endowed with human rights. In some instances, this knowledge fueled and supported campaigns to secure legal rights where they had been denied. Further, countless political leaders have repeatedly lauded the virtues of economic growth and the expansion of economic opportunities as core objectives of responsible governments. Those who have sought to continue defending some forms of state welfare programs have repeatedly stressed the necessity of economic growth as the means of supporting the range of welfare services funded by the state to provide for those who have not been able to share in the purported benefits of neoliberal-induced growth. Finally, the gentrification of previously rundown and deprived swathes of many urban and suburban neighborhoods stand as architectural monuments to neoliberal "regeneration."

There is also a far darker side to these developments. While some economists identify neoliberalism with the fastest growing material inequalities in human history, others have documented the emergence of decidedly ungentrified social groups, which bear the greatest brunt of this rising inequality. Thus, Guy Standing coined the term the "precariat" to designate a rapidly expanding social demographic that is chiefly characterized by the precariousness of its existence and that lives in chronic conditions of insecurity. ${ }^{49}$ Standing seeks to identify the distinct socio-economic suffering of an expanding constituency of people residing in some of the most affluent societies on earth. ${ }^{50}$ The precariat is a large and growing constituency, including the young, the old, the frail, the chronically ill and disabled, migrant workers, refugees and asylum seekers, the unemployed, the many in employment but on zero contract hours, and many others who may not yet be considered bona fide members of this unenviable constituency but for whom the loss of an increasingly insecure livelihood might result in them becoming "precariatized." ${ }^{51}$

Regardless of how we socially classify them, there are also very large numbers of people exposed to severe forms of deprivation, inequality, and marginalization in some of the wealthiest, most neoliberal societies on earth. As a recent UN report into the extent of poverty and inequality in the US demonstrated, some 40 million Americans live in poverty. ${ }^{52}$ The youth poverty rate in the US is the highest within the OECD and the US ranks 36 out of 37 for access to water and sanitation. ${ }^{53}$ Tropical diseases and parasites such as Zika and hookworm are increasingly prevalent in some areas of the southern United States. ${ }^{54}$ Philip Alston, the author of the report and the current UN Special Rapporteur on extreme poverty and human rights stated:

the United States is alone among developed countries in insisting that while human rights are of fundamental importance, they do not include rights that guard against dying of hunger, dying from a lack of access to affordable healthcare, or growing up in a context of total deprivation. ${ }^{55}$ 
Interestingly, Alston focused his report on the effects that poverty exerts on many Americans' enjoyment of their civil and political rights in recognition of the United States refusal to ratify the International Covenant on Economic, Social and Cultural Rights. ${ }^{56}$ One might therefore conclude that the United States' narrow construal of the definition of human rights makes it an inappropriate case study for any argument concerning the ineffectiveness of more comprehensive human rights protection to combat the effects of inequality. It would therefore be better to examine examples of states that have both endorsed a range of comprehensive human rights instruments and where the precariat exists in large numbers. The United Kingdom provides a perfect example.

Almost all (if not all) post-industrial, neoliberal societies contain a highly established, legally-enshrined human rights infrastructure, comprising an extensive body of positive law and distinct institutions. The United Kingdom is exemplary in this respect. ${ }^{57}$ The UK is party to all of the core UN human rights covenants. It is similarly bound by the terms of the European Convention on Human Rights and the European Social Charter. There exists, for the moment at least, the UK Human Rights Act and a UK parliamentary human rights committee. The UK has an independent human rights commission and a well-established and varied human rights NGO sector. The UK ticks most, if not all, of the institutional human rights boxes. And yet, the UK has also been experiencing growing levels of inequality. Significant parts of the UK population are exposed to and suffering from increasing levels of deprivation, inequality, and marginalization. A select sample of indicators illustrates this growing inequality.

The "UK is the seventh most unequal" society within the OECD. ${ }^{58}$ In the UK, the richest 10 percent of the population owns 45 percent of the nation's wealth, while the poorest 50 percent owns 8.7 percent of the wealth. ${ }^{59} \mathrm{~A}$ quarter of all children in the UK live in poverty. ${ }^{60}$ Additionally, 1.6 million pensioners live in poverty. ${ }^{61}$ Over 5 million adults are functionally illiterate and UK teenagers are the most illiterate and innumerate within the OECD countries. ${ }^{62}$ Between April 2016 and March 2017, Trussell Foodbank distributed over 1 million emergency three-day food parcels to people who could not afford to feed themselves or their families. ${ }^{63}$ Figures from the Office for National Statistics show that malnutrition was the underlying cause or a contributory factor in 391 deaths in NHS hospitals in England and Wales in 2016. ${ }^{64}$ In light of these statistics, the post-materialist claim that poverty no longer kills people in post-industrialized societies holds no weight.

Levels of deprivation, inequality, and marginalization have been growing rapidly since the late 1970s in the UK. For the most part, successive governments have either largely ignored this phenomenon, or tended towards characterizing it in terms that both stigmatize the victims and lends support to a policy approach marked by greater restrictions and conditions in the provision of welfare benefits. ${ }^{65}$ Political discourse regarding the existence of poverty and inequality within the UK has both shaped and reflected a wider depiction of welfare claimants as being either bogus, or in some sense ultimately responsible for their needs, expecting others to then support and provide for them.

This narrative, while still prevalent, was shaken and partially disrupted by a particularly shocking tower block fire in a social housing estate in west London: the 
Grenfell Tower fire, which occurred on the night of 14 June 2017. Grenfell Tower was a twenty-four-storey social housing tower block situated on a larger social housing estate, many of whose residents would fall into Standing's category of the precariat. A domestic fire occurred in one of the flats and within a very short period of time, quickly engulfed the entire block. The rapid spread of the fire was largely due to the highly flammable cladding, which had recently been installed as part of a wider "modernizing" refurbishment. The official death toll reached seventy-one. ${ }^{66}$ Following the Grenfell conflagration, 259 other similar tower blocks across the UK have failed fire stress tests. ${ }^{67}$

The horrendous event, which was the Grenfell Tower fire, terribly exemplifies a far darker side to gentrification in both the narrow and broader sense of the term. Grenfell is located in one of the wealthiest residential neighborhoods in the world. The average price of an apartment in the Royal London Borough of Kensington and Chelsea was over $£ 1.5$ million in 2016. A semi-detached house in the borough costs over $£ 6$ million. A wall separates part of the estate from its private owner-occupied properties found in the same area. It was not always this way. Large areas of the borough were previously inhabited by mostly working-class residents, but gentrification has spread rapidly and most of the former inhabitants have left, as social housing estates, like the one Grenfell was situated on, have given way to private residential expansion. In some cases, the government has made limited provision for social housing tenants in newly built residential complexes. However, in many of these, the social housing and so-called market-value residents have separate entrances to the very same building, effectively segregating the poor from the better off. These segregated entrances have been dubbed "poor doors."68

Given the demographics of Grenfell, it is not surprising that many have come to view it as a symbol of life-threatening inequality in the UK. ${ }^{69}$ In contrast, others have sought to represent the fire as a tragedy whose significance and meaning only extends to the victims and their families. ${ }^{70}$ This view typically focuses on the need for an inquiry and, if necessary, the launching of criminal corporate manslaughter charges against Kensington Borough Council and the private tenant management organization that managed the block for the council. ${ }^{71}$ In this way, an attempt is made to individuate and de-politicize Grenfell and to divert attention away from situating its victims in a broader socio-economic and socio-political context, which affects vast swathes of the UK..$^{72}$ One might expect this tactic from those who have distinct and partial political interests in seeking to deny the existence and extent of structural and systemic inequality within the UK. What one might not have expected is that, in its immediate response to Grenfell, much of the UK human rights community, where it commented at all, similarly ignored its political significance. Thus, Amnesty International UK (with 7 million members worldwide) made no statement at all on Grenfell. Liberty called for a thorough public inquiry, adequate provision of legal aid, and a speedy return of residents to their community. ${ }^{73}$ The Equality and Human Rights Commission published a blog, which mentioned Grenfell in espousing the importance of economic and social rights within the UK, before insisting that a key objective of any post-Brexit settlement must be "to retain and strengthen rights in UK law and to keeping Britain's long track record of fairness intact."74 Human Rights Watch also blogged on the issue and similarly focused on the redress aspect of the fire, by stating that "the government must ensure effective independent investigations into the causes of the deaths in the fire, with appropriate 
remedies, including criminal accountability, compensation for victims, and necessary changes to laws and policies." 75 Finally, Rights Info continued the blogging response theme and insisted that the private contractors should have sought to comply with the aforementioned UN Guiding Principles on Business and Human Rights. ${ }^{76}$

The UK human rights community's general response to Grenfell echoes its general lack of engagement with neoliberalism and the plight of the precariat. ${ }^{77}$ As such, it confirms many of the core components of the gentrification of human rights, which I presented above. It fails to consider the possibility that the plight of the precariat may be due to structural and systemic forms of inequality. It even, in the words of the Equality and Human Rights Commission blogger, reaffirms a belief that the UK is basically a fair and just society. ${ }^{78}$ Similarly, the community makes no attempt to consider the possible effects of gentrification (in the narrow sense) on Grenfell specifically, and the conditions under which many other social housing tenants live. ${ }^{79}$ Liberty's call for residents to be returned speedily to their community may be well intentioned, but entirely ignores the deprived conditions of the communities to which they would be returned. Most of the respondents made recommendations that merely reinforced the existing institutions and none questioned whether, for example, a right of individual legal remedy or redress might fall far short of addressing the collective, systemic challenges of deprivation, inequality, and marginalization in the UK. The present institutions might just be part of the problem and not the solution. Finally, the various organizations made no comment about the socio-economic class aspect of the plight of the precariat and the victims of Grenfell especially. The British government conducted an independent inquiry into the fire, although the local residents' association repeatedly criticized the terms of that inquiry for excluding the broader socioeconomic context of Grenfell. The burnt-out building remains and there can be little doubt that Grenfell disrupted the relentlessly critical narrative that sought to blame the poor for their own plight. However, there have been no systematic policy proposals to identify and begin to seek to overcome the far wider extent of deprivation, inequality, and marginalization within the UK. Grenfell symbolizes this wider state of deprivation, inequality, and marginalization.

\section{HAVING THE COURAGE TO ENGAGE IN AN ATTACK ON ONE'S CONVICTIONS: DE-GENTRIFYING HUMAN RIGHTS?}

I have argued that the ability of human rights to genuinely and concertedly confront the systemic and structural causes of increasing deprivation, inequality, and marginalization has been severely restricted by what I have termed the gentrification of human rights. Human rights rose to become the dominant political idiom for many within notionally liberal-democratic societies as a consequence, in part, of the community's general failure to identify and challenge the pervasive harms which neoliberalism has entailed. The human rights community, as I have been using that term throughout, may be understood not so much as directly supporting neoliberalism, but as failing to robustly and concertedly challenge it. The prevailing failure of human rights is one of omission, rather than commission. However, the effects of this failure have been amplified as a consequence of the doctrine's status as the predominant political idiom, or discourse, of social justice within affluent, liberal-democratic societies. ${ }^{80}$ As others have argued, the sheer degree of faith placed in human rights by many who identify it with the pursuit of social justice has hegemonically restricted our collective engagement with the deeper causes of 
deprivation, inequality, and marginalization. In their gentrified form, in particular, human rights have more often than not restricted the political imagination to a series of provisions that largely reinforce the deeper causes of so much injustice. On its face, depicting human rights as "gentrified" in the ways I have done in this article could support a remorselessly critical analysis of human rights as providing nothing more than an ideological alibi for constituencies of people whose social conditions depend upon the systemically hierarchical relationships, which gentrification both depends upon but simultaneously seeks to deny. That is not my intention here. Critique need not be crudely adversarial or thoroughly oppositional.

Despite this, and given the strong tendency within the human rights community generally towards rejecting all forms of critical engagement, many within the human rights community are liable to disagree and perhaps even take offence at my characterization of significant components of human rights as gentrified within affluent, "liberal-democratic" societies. Many will direct me towards the existence of an extensive body of social rights, which many human rights defenders have dedicated their work to developing and promoting. Even some prominent critics of the failures of human rights to effectively protect and promote material equality, such as Moyn for example, also identify social rights as the means by which human rights may begin to confront its limitations and overcome its embarrassing entanglement with neoliberalism. ${ }^{81}$ There can be no question that the defense of social rights has much to commend it, particularly perhaps given the sheer extent and depth of social inequalities in otherwise such affluent societies. The bold and uncompromising country reports produced by the present UN Special Rapporteur on extreme poverty and human rights offer an example of the contribution that human rights can make to denounce the precariatization of affluent societies. ${ }^{82}$ Similarly, Grenfell has coincided with a renewed interest in social rights amongst sections of human rights academia and the NGO sector in the UK. ${ }^{83}$ In this regard, human rights can best detach itself from its complicity with neoliberalism by pivoting towards social democratic principles and aligning itself with that category of rights which neoliberalism appears so adamantly to oppose.

In immediately pragmatic terms, a greater interest in and support for social rights is, I believe, to be welcomed by all of those within the human rights community who are genuinely and deeply aggrieved by rising inequality. However, I doubt that even this will enable the community to genuinely de-gentrify itself. Alston's damning report of extreme poverty in the US was summarily dismissed by the current US administration and even accused of overt political bias. The report may have energized some community activists who are struggling against pervasive poverty and destitution in many parts of the US (which could be a beneficial consequence) but it is not going to change the core policy commitments of an administration that continues to claim that the US is a "world leader" in defending human rights. ${ }^{84} \mathrm{By}$ itself, mere outrage at others' plight offers little, if any, effective means for overcoming the injustices to which individuals are most exposed. Similarly, individual compensation and redress for the victims of the Grenfell fire will, in itself, yield little or no beneficial consequences for the many people for whom homelessness is the only alternative to continuing to live on social housing estates separated by real and metaphorical walls from their owneroccupier private counterparts. 
Most certainly in respect to the manner of their application, and quite possibly in respect to their very formulation, social rights are only capable of providing contingent, ameliorative, and palliative redress and thereby leave intact the very relationships of inequality and profound unfairness that gave rise to them in the first place. ${ }^{85}$ The recipients of social rights become, perhaps inevitably, "patients" of liberal, human rights concern, a relationship based upon terms of exchange, which all too quickly and on too many occasions, succumbs to all of the contradictions of any such form of noblesse oblige. ${ }^{86}$

There is an urgent need for the doctrine and the community to de-gentrify if human rights is to genuinely stake a claim to a deserved status of being a key political idiom for social justice in these times of rapidly increasing deprivation, inequality, and marginalization. A mere acknowledgement of the validity of the social rights entitlements by the "have-nots" in our societies, which does not radically engage with the deeper conditions that produce both the integral relationships between the "haves" and the "have-nots," will provide superficial redress at best.

There is an even more immediate need for the human rights community to both acknowledge its own gentrification and to engage in the task of overcoming it: the increasing electoral hostility directed towards human rights within those societies in which demagoguery, the crack cocaine of contemporary politics, is on the rise. It would be absurdly reductivist to attribute all of the rising popularity of demagoguery to liberalism's failure to effectively engage with the deprivation, inequality, and marginalization to which neoliberalism, in particular, has contributed. Voters are drawn towards demagoguery for a diverse set of "reasons" and ostensive interests. It is also understandable why, given the overwhelmingly illiberal and intolerant character of so much of demagoguery, so many liberal human rights supporters would prefer to label these as "deplorable" and refuse to engage with them. I have already insisted that, in a notional democracy, any such summarily dismissive attitudes towards fellow voters and citizens are pragmatically ill-advised. However, as this article has sought to identify and unpack, the human rights community's growing unpopularity amongst many electorates, where human rights were thought (by the human rights community) to be secure, may be considered a consequence of the failure to engage with the conditions that demagogues have come to exploit for their own purposes. It is easy to depict liberalism as having failed many, precisely because it has failed so many. The atavistic and self-destructive appeal of authoritarian demagogues is, in part, a reaction to the hubristic failure of gentrification to be the tide that lifts all boats, to repeat the imagery I considered earlier. ${ }^{87}$ The human rights community has a profound interest in disassociating itself from such prejudices and false assumptions, not just because this is pragmatically advisable within electoral democracies, but because there is an urgent need to develop and disseminate a radical political response to demagoguery. If human rights is to play an important role in this movement, it will have to recognize the need for radical change. ${ }^{88}$ In part, the human rights community's reaction to critiques such as this will indicate whether it has the ability to do so. 


\section{Footnotes}

1. See Kathryn Sikkink, Evidence for Hope: Making Human Rights Work in the 21st Century (2017) for a defense of the continuing benefits of the contemporary human rights movement against some of its recent critics. In contrast, Samuel Moyn, Not Enough: Human Rights in an Unequal World (2018) has consistently criticized human rights for its failure to realize its own modest socio-economic objectives. My own approach is sympathetic to Moyn's general approach but extends beyond what is, in effect, the social-democratic position on which he bases his critique of human rights.

2. I have a number of objections to the routine labelling of any and all forms of politically intolerant beliefs and practices as "populist." By designating political opposition to liberalism as populist, one both over-inflates the support such opposition currently enjoys and runs the risk of adding to that support by lending weight to the claim that the liberal status quo, which demagoguery challenges, is elitist, since whatever opposes is must be populist. See Chantal Mouffe, For a Left Populism (2018); Jan-Werner Müller, What is Populism? (2016) for two differing evaluations of contemporary populism. I shall provide a detailed analysis of the relationship between populism and human rights in a subsequent publication.

3. Just how long human rights has enjoyed such a status is disputed. While the conventional understanding is that human rights was a direct and morally compelling response to the horrors of the Holocaust, Samuel Moyn, The Last Utopia: Human Rights in History (2010) has offered an alternative historical account, which points to the 1970s as the time when human rights rose to prominence within liberal-democratic societies. Moyn's methodology has been criticized, but my own ensuing analysis of the development of the human rights community and movement broadly follows Moyn's chronology for reasons which will become clear.

4. $\quad$ Throughout this article, I refer to "the human rights community." I do not mean to imply by this that there exists a discrete, homogeneous, and internally uniform group of human rights professionals, activists, and supporters. My understanding is not essentialist. Nor will my critical analysis of the human rights community apply as forcefully to all who seek to defend or align with human rights. Rather, my analysis seeks to target what I shall claim are highly influential or dominant features and attributes of the human rights community and movement within affluent, "Western" societies within which human rights are increasingly challenged domestically.

5. Makau Mutua, Human Rights: A Political and Cultural Critique (2002).

6. Clinton made reference to the "deplorables" who supported Donald Trump's presidential campaign at a fund-raiser event on Friday 9 September 2016. She stated that "'You know, to just be grossly generalistic, you could put half of Trump's supporters into what I call the basket of deplorables. Right?"' she said to applause and laughter. "'The racist, sexist, homophobic, xenophobic, Islamaphobic-you name it. And unfortunately there are people like that. And he has lifted them up."' Amy Chozick, Hillary Clinton Calls Many Trump Backers "Deplorables," and G.O.P. Pounces, N.Y. Times (10 Sept. 2016), https://www.nytimes.com/2016/09/11/us/politics/hillary-clinton-basket-of-deplorables.html.

7. At a presentation of an earlier version of this article, a colleague put it to me that my entire approach was undermined by my alleged "liking" for the "deplorable." My colleague's misunderstanding of my motivations for writing the article speaks volumes about what I shall proceed to demonstrate to be a deeply damaging approach, which too many within the human rights community harbor: that a close normative affinity with others is a prerequisite for defending others' human rights. How could a political ethics which claims universality be founded upon such affinities?

8. Capitalism resembles those commercial enterprises which repeatedly re-brand themselves whilst continuing to nevertheless engage in essentially the same set of structured activities. When all is said and done, capitalism essentially prioritizes the maximization of profit over the core and equal interests of human beings. Human well-being is, at best, an instrumental or incidental concern for all forms of capitalism. It may be that we are presently witnessing significant alterations to neoliberal capitalism but there is no reason to believe that any such 
alterations will result in economically and socially just conditions emerging from them. My own analysis and reading of capitalism draws upon some of the analysis conducted by the Early Frankfurt School and, more recently the highly-important work of Thomas Pikkety. See Thomas Piketty, Capital in the Twenty-First Century (Arthur Goldhammer trans., 2014).

9. See The IMF at a Glance, Int'L Monetary Fund (26 Feb. 2019), https://www.imf.org/en/About/Factsheets/IMF-at-a-Glance; What We Do, The World Bank, https://www.worldbank.org/en/what-we-do.

10. What We Do, supra note 9 .

11. See Paul Hunt, Reclaiming Social Rights: International and Comparative Perspectives (1996).

12. David Harvey, A Brief History of Neoliberalism 176 (2005).

13. Id.

14. Moyn, The Last Utopia, supra note 3.

15. Id.

16. Moyn, Not Enough, supra note 1. I think Moyn's analysis is unduly affected by a US-centric perspective, which has always subordinated social rights. I shall argue in the final section that the kind of social-democratic motivations which call for greater provision of social rights, while immediately desirable in many instances, are nevertheless still focused on the symptoms of problems which have deeper sources, while also often simply sustaining hierarchical relationships in which the would-be recipients of greater social right provision are still conceived of as "patients" rather than agents.

17. Michael Ignatieff, Human Rights as Politics and Idolatry, in Human Rights as Politics and Idolatry, 3-98 (Amy Gutmann ed., 2001).

18. I am using the term gentrification as a trope, or a term-of-art. While I will consider the narrower usage and draw upon it, it is important to understand the term in a broader sense. This includes and encompasses a collection of normative and dispositional attributes and commitments, which closely coincide with those that David Harvey (Harvey, supra note 12), and Naomi Klein (Naomi Klein, The Shock Doctrine: The Rise of Disaster Capitalism (2007)) in particular identify as key to human rights entwinement with the philosophy and practices of neoliberalism.

19. The reference to attempting to live wrong life rightly is to Theodor Adorno's analysis of home ownership within late capitalist societies. See Theodor Adorno, Minima Moralia:Reflections from Damaged Life 39 (E.F.N. Jephcott trans., 1974). Readers familiar with Adorno's social critique will recognize his influence on my understanding of the predominance of exchange value.

20. Ruth Glass \& John Westergaard, London's Housing Needs: Statement Of Evidence to the Committee On Housing in Greater London, Centre for Urban Studies, (1965).

21. Andres Duany, Three Cheers for "Gentrification," Am. Enterprise, Apr./May 2001, at 37 (emphasis added).

22. J. Peter Byrne, Two Cheers for Gentrification, 46 How. L.J. 405, 406 (2003).

23. Id. at 419 .

24. Id. at 421.

25. Id. at 422.

26. In stark contrast to such positive evaluations of gentrification, there is an extensive body of literature that indicates the extent to which gentrification often displaces the poor and 
significantly reduces the diverse demographics of many such neighborhoods. See Tom Slater, The Eviction of Critical Perspectives from Gentrification Research, 30 Int'l J. Urb. \& Regional Res. 737 (2006); Miriam Zuk et al., Gentrification, Displacement and the Role of Public Investment: A Literature Review, (Community Dev. Inv. Ctr., Working Paper 2015-05, 2015); James Jennings, Gentrification as Anti-Local Economic Development: The Case of Boston, Massachusetts, 23 Trotter Rev. 1 (2016).

27. There is a very large body of research exploring this phenomenon. See Alvin W. Gouldner, The Future of Intellectuals and the Rise of the New Class (1979); Ronald Inglehart, The Silent Revolution: Changing Values and Political Styles Among Western Publics (1977); Alberto Melucci, The End to Social Movements?: Introductory Paper to the Sessions on "New Movements and Change in Organizational Forms," 23 Soc. Sci. Info. 819 (1984).

28. Moyn, The Last Utopia, supra note 3; Samuel Moyn, A Powerless Companion: Human Rights in the Age of Neoliberalism, 77 L. \& Contemp. Probs. 147 (2014); Moyn, Not Enough, supra note 1. Samuel Moyn, (2010, 2014 and 2018) has devoted particular attention to the relationship between neoliberalism and human rights during the 1970s. He neglects to consider the new middle classes and post-materialism, however. It is my view that these latter concepts have played a more direct role in the social diffusion of interest in human rights.

29. Daniel Bell, The Coming of Post-Industrial Society: A Venture in Social Forecasting (1973).

30. Inglehart, supra note 27 , at 22 .

31. Peter L. Berger, The Capitalist Revolution: Fifty Propositions About Prosperity, Equality, and Liberty (1986); Jan Willem Duyvendak, The Power of Politics: New Social Movements in France (1995).

32. Barbara Epstein, Political Protest and Cultural Revolution: Nonviolent Direct Action in the 1970 S and 1980S (1991); Hanspeter Kriesi, Political Mobilization and Social Change: The Dutch Case in Comparative Perspective (1993).

33. Gouldner, supra note 27.

34. Frank Parkin, Middle Class Radicalism: The Social Bases of the British Campaign for Nuclear Disarmament 40-41 (1968).

35. Pierre Bourdieu, La Distinction: Critique Sociale du Jugement (1979); Klaus Eder, The New Politics of Class: Social Movements and Cultural Dynamics in Advanced Societies (1993).

36. Melucci, supra note 27; Alastair Bonnett, The Formation of Public Professional Radical Consciousness: The Example of Anti-Racism, 27 Soc. 281 (1993); David Ley, Gentrification and the Politics of the New Middle Class, 12 Env't \& Plan. D: Soc'y \& Space 53 (1994).

37. Claus Offe, New Social Movements: Challenging the Boundaries of Institutional Politics, 52 Soc. Res. 817 (1985); Eder, supra note 35.

38. Inglehart, supra note 27.

39. Steven Brint, "New-Class" and Cumulative Trend Explanations of the Liberal Political Attitudes of Professionals, 90 Am. J. Soc. 30 (1984); John W. Cleveland, Does the New Middle Class Lead Today's Social Movements?, 29 Critical Soc. 163 (2003).

40. Gouldner, supra note 27, at 83 .

41. Id. at 7 .

42. Ignatieff, supra note 17 . 
43. This argument for reducing what human rights should hope to achieve was outlined by Ignatieff, supra note 17 in his oft-cited contribution to the Tanner Lectures. While Ignatieff claimed to be expounding a distinctly political approach to human rights and has been widely accepted as doing so, Wendy Brown, "The Most We Can Hope for ... ": Human Rights and the Politics of Fatalism, 103 South Atlantic Q. 451 (2004) has argued that Ignatieff's account of human rights aims at avoiding political engagement, rather than providing a means for staking out political positions.

44. Inglehart, supra note 30 , at 22.

45. Central to this view is also the significance placed on the existence of human rights law as denoting and defining human rights. Allen Buchanan, The Heart of Human Rights (2013) has recently reiterated that international human rights law is the answer to the question, what are human rights?

46. Although the wording here implies that such positions explicitly argue that capitalism, or economic relations more generally, are ultimately a matter for democratic deliberation and decision-making, this is rarely explicitly advocated within this position.

47. Rhoda E. Howard-Hassmann, Reply to Paul O'Connell's Article on Neo-Liberal Globalisation and Human Rights, 9 Hum. Rts. L. Rev. 127, 133 (2009); David Kinley, Civilising Globalisation: Human Rights and the Global Economy 1-3 (2009).

48. Sikkink, supra note 1.

49. Guy Standing, The Precariat: The New Dangerous Class (2011).

50. Id. See also Pierre Bourdieu et al., The Weight of the World: Social Suffering in Contemporary Society (Priscilla Parkhurst Ferguson et al., trans., 1999) for another recent and very wideranging study on social suffering in highly affluent, but pathologically unequal societies.

51. Standing, supra note 49.

52. Special Rapporteur, Report of the Special Rapporteur on Extreme Poverty and Human Rights on His Mission to the United States of America, U.N. Office of the High Comm'r for Hum. Rts. (OHCHR), U.N. Doc. A/HRC/38/33/Add. 1 (2018) (by Philip Alston), [Hereinafter Report of the Special Rapporteur on Extreme Poverty].

53. Id.

54. Id.

55. Andrew Fagan, The United States: A World Leader in Human Rights?, Univ. of Essex, Human Rights Ctr. Blog (27 June 2018).

56. Report of the Special Rapporteur on Extreme Poverty, supra note 52.

57. I focus on the UK because I am most familiar with the plight of the precariat there. Other postindustrial, neoliberal societies will also be subject to very similar general conditions as exist in the UK.

58. The Scale of Economic Inequality in the UK, The Equality Tr. (2017), https://www.equalitytrust.org.uk/scale-economic-inequality-uk.

59. Id.

60. Child Poverty Statistics and Facts, Barnardo's (2017), https://www.barnardos.org.uk/what_we_do/our_work/child_poverty/child_poverty_what_is_pov erty/child_poverty_statistics_facts.htm. 
61. How We Can End Pensioner Poverty, Age UK (2017), http://www.ageuk.org.uk/professionalresources-home/policy/money-matters/poverty-and-inequality/.

62. Adult Literacy, Nat'l Literacy Tr. (2017), https://literacytrust.org.uk/parents-and-families/adultliteracy/.

63. End of the Year Stats: "Benefit Levels Must Keep Pace With Rising Cost of Essentials" Record Increase in Foodbank Figures, The Trussell Tr., (2019), https://www.trusselltrust.org/news-andblog/latest-stats/end-year-stats/.

64. Ben Glaze, Number of Brits Dying of Malnutrition or Hunger is Soaring, Shock Figures Reveal, Mirror (11 Aug. 2016, 9:00 PM), http://www.mirror.co.uk/news/uk-news/number-brits-dyingmalnutrition-hunger-8611991.

65. For example, the former UK Prime Minister characterized Britain as being "broken" in numerous speeches throughout 2011, following widespread rioting in several major English cities. See Richard Heyton, Fixing Broken Britain, in Cameron and the Conservatives: The Transition to Coalition Government 136 (Timothy Heppell \& David Seawright eds., 2012) for an analysis of this concept and claim.

66. Kevin Rawlinson et al., Grenfell Tower Final Death Toll: Police Say 71 Lives Lost as Result of Fire, The Guardian (16 Nov. 2017), https://www.theguardian.com/uk-news/2017/ nov/16/grenfell-tower-final-death-toll-police-say-71-people-died-in-fire.

67. Where Have Cladding Fire Tests Failed?, BBC News (19 July 2017), http://www.bbc.com/news/uk-40396448.

68. Lucy Pasha-Robinson, Grenfell Tower: Social Housing Resident Reveals "Segregation" of Rich in Luxury Developments, The Independent (23 June 2017), http://www.independent.co.uk/news/uk/home-news/grenfell-tower-latest-social-housingsegregation-luxury-apartment-blocks-poor-doors-lbc-james-obrien-a7804561.html.

69. It should be noted that the UK has not entered rights to housing from international human rights law into domestic UK law.

70. Embers Still Glowing: The Ramifications of Grenfell Tower Fire Continue to Spread, The Economist (24 June 2017), https://www.economist.com/britain/2017/06/24/the-ramifications-ofthe-grenfell-tower-fire-continue-to-spread.

71. Samuel Osborne, Grenfell Tower: Sentences for Gross Negligence Manslaughter Could Increase After Investigation Into Deadly Fire, Independent (31 July 2018), https://www.independent.co.uk/news/uk/crime/grenfell-tower-latest-gross-negligencemanslaughter-jail-sentence-fire-a8470596.html.

72. Embers Still Glowing, supra note 70 .

73. Emma Norton, What the Government Must Do After the Grenfell Tower Fire, Liberty (15 June 2017), https://www.libertyhumanrights.org.uk/news/blog/what-government-must-do-aftergrenfell-tower-fire.

74. David Isaac, Queen's Speech: Missed Opportunity for Equality and Healing Divisions, Equal. \& Hum. Rts. Commission (29 June 2017), https://www.equalityhumanrights.com/en/ ourwork/blogs/queen\%E2\%80\%99s-speech-missed-opportunity-equality-and-healing-divisions.

75. Benjamin Ward, After UK's Grenfell Tower Blaze, Human Rights Can Help, Hum. Rts. Watch (21 June 2017), https://www.hrw.org/news/2017/06/21/after-uks-grenfell-tower-blaze-humanrights-can-help. 
76. Anna Dannreuther, How the Grenfell Tower Fire is a Business and Human Rights Issue, Rts. Info (16 June 2017), https://rightsinfo.org/how-the-grenfell-tower-fire-is-a-business-and-humanrights-issue/.

77. One notable exception to this general rule can be found in the on-going campaigns of Just Fair. See, e.g., Submission to the Grenfell Tower Inquiry Consultation on Terms of Reference, Just Fair (28 July 2017), http://docs.wixstatic.com/ugd/8a2436_c60968b318 1e4635a53209a6a8108120.pdf.

78. Issac, supra note 74 .

79. Interestingly, and after the completion of an earlier draft of this article, the Equality and Human Rights Commission announced in early December 2017 that they were pursuing their own inquiry into the Grenfell Tower. The planned EQHC inquiry will specifically examine the broader socioeconomic context of the fire, which the UK Government had explicitly excluded from its on-going (and heavily criticized) inquiry. This is a significant and highly welcome development. However, I do not believe that, by itself, it undermines my broader evaluation of the UK human rights community in this respect.

80. See Wendy Brown, States of Injury: Power and Freedom in Late Modernity (1995) for a detailed argument that the predominant status of human rights has served to restrict the radical political imagination and subsequent political engagements within liberal-democratic societies.

81. Moyn, Not Enough, supra note 1.

82. For access to Philip Alston's other country reports under the mandate of the UN Special Rapporteur for extreme poverty and human rights see Special Rapporteur on Extreme Poverty and Human Rights, United Nations Hum. Rts. Office High Commissioner, https://www.ohchr.org/en/issues/poverty/pages/srextremepovertyindex.aspx.

83. My colleague, Paul Hunt, at the University of Essex, is particularly outstanding in this regard. See Paul Hunt, Social Rights Are Human Rights: But the System is Rigged (2017).

84. Fagan, supra note 55; Report of the Special Rapporteur on Extreme Poverty, supra note 52.

85. David Kennedy has presented a similar critique of the capacity of human rights to effectively address systemic inequalities. He writes, "human rights foregrounds problems of participation and procedure, at the expense of distribution, implicitly legitimating the existing distributions of wealth, status and power in societies once rights have been legislated, formal participation in government achieved, and institutional remedies for violations provided." David Kennedy, The International Human Rights Movement: Part of the Problem?, 15 Harv. Hum. Rts. J. 101, 109 (2002).

86. Iris Marion Young's important insight into distributive justice's narrow focus on the distribution of goods and resources is relevant here since what is required is a radical re-organization of social relationships. The exclusive focus on gaining more goods typically leaves hierarchical relationships largely intact. Iris Marion Young, Justice and the Politics of Difference (1990).

87. Duany, supra note 21.

88. I intend to engage with the way in which human rights might pursue a form of degentrification in a subsequent publication. Suffice it to say, the approach I shall pursue will be influenced by the need for human rights to, in Wendy Brown's terms, identify and overcome "codify[ing] and entrench[ing] existing social relations" and how they might "directly contest or transform them., at contest or transform themud" Brown, supra note 80 , at 12. I also believe that the degentrification of human rights will involve developing what Paolo Freire has termed an "ethic of solidarity", in which "[s]olidarity requires that one enter into the situation of those with whom one is solidary." Paolo Freire, Pedagogy of the Oppressed, 49 (Myra Bergman Ramos trans., 1970). A central objective of any such renewed approach to human rights will need to emulate what Cornel West has argued for when he states that "[o]ne major challenge for progressive politics 
is to find a way of channeling the talent and energy of poor people into forms of social motion that can have impact on the powers that rule." Cornel West, The Role of Law in Progressive Politics, in The Politics of Law: A Progressive Critique, 708, 712 (David Kairys ed. 3d ed., 1998). Developing an ethic of solidarity within human rights will also draw upon Iris Marion Young's critique of the prevailing models of distributive justice and their undue focus on the distribution of goods and resources. See Young, supra note 86. 